
\title{
28 Research Square \\ Effect of Poverty Volatility on Tax Revenue Instability in Developing Countries
}

SENA KIMM GNANGNON ( $\nabla$ kgnangnon@yahoo.fr )

World Trade Organization (WTO)

\section{Research Article}

Keywords: Poverty volatility; Poverty rates; Tax Revenue Instability.

Posted Date: August 31st, 2020

DOI: https://doi.org/10.21203/rs.3.rs-66375/v1

License: (c) (i) This work is licensed under a Creative Commons Attribution 4.0 International License. Read Full License 


\section{Abstract}

This paper complements the relatively few existing studies on the macroeconomic effects of poverty in developing countries, by investigating the effect of poverty volatility on tax revenue instability. The empirical analysis has been conducted using an unbalanced panel dataset of 112 developing countries covering the period 1980-2017, and primarily the two-step system Generalized Method of Moments technique. Findings have revealed that, on average, over the full sample, poverty volatility is associated with lower tax revenue instability. However, this reflects differentiated effect across countries, as lowincome countries tend to experience a positive tax revenue instability effect of poverty volatility, while poverty volatility results in lower tax revenue instability in relatively advanced countries (among developing countries). Additionally, these outcomes hide the fact that poverty volatility exerts a higher positive effect on tax revenue instability in the context of increasing poverty rates. From a policy perspective, this analysis shows that it is essential for policymakers to dampen the volatility of poverty rates (notably in countries with high poverty rates) if they were to ensure the stability of tax revenue or reduce its instability, given the adverse effect of tax revenue instability on economic growth.

\section{Introduction}

Poverty, whose persistence can have devastating effects on people's life, can be considered as a selfreinforcing phenomenon, which constrains the growth of an individual's wealth (e.g., Azariadis and Stachurski, 2005; Barrett and Carter, 2013). This self-reinforcing phenomenon arises from a variety of elements, of which financial factors (for example, access to low return assets), the cost of set-up hightech equipment, political economy aspects such as imperfect markets, credit constraints to the adoption of better technology, and differentiated opportunities (e.g., Barrett and Carter, 2013; Barrett et al., 2015; Banerjee and Newman, 1993; Mirza et al., 2019). Reducing poverty has been a long-standing concern for policymakers at both the national and international levels. In the recent decades, the interest of the international community in addressing the poverty issue around the world has been reflected in the adoption of eight Millennium Development Goals[1] (MDGs), the first of which was to halve extreme poverty by the target date of 2015. At the United Nations Sustainable Development Summit in New York in September 2015, the Members of the United Nations adopted seventeen Sustainable Development Goals[2] (SDGs), which replaced the MDGs, and aim at promoting sustainable development in all countries. Once again, poverty reduction is at the heart of this set of goals, as the first SDG aims to end poverty in all its forms everywhere (see page 14 of the United Nations document A/RES/70/1).

A voluminous literature has been devoted to the factors, including the macroeconomic ones, that underpin the dynamics of poverty in developing countries. However, a limited empirical literature has looked at the macroeconomic effects of poverty. For example, some studies have examined the effect of poverty on human capital (e.g., Azariadis and Stachurski, 2005; Bain et al. 2013; Bowles et al., 2006; Haushofer and Fehr, 2014; Perkins et al., 2012) and on economic growth (e.g., Bagchi and Svejnar, 2015; Breunig and Majeed, 2020; López and Servén, 2015; Ravallion, 2002, 2012). Others have focused on the 
effect of poverty on economic development (e.g., Mehanna, 2004; Nakabashi, 2018), export product diversification (Gnangnon, 2019a), and trade openness (Gnangnon, 2019b).

A recent literature, although very nascent, has considered the issue of poverty volatility, i.e., ups-anddowns movements of poverty levels (rates). One of the scarce papers on this matter is that of Jefferson (2008), who has shown that the volatility of the aggregate economic activity (i.e., output volatility) is an important determinant of poverty volatility. The issue of poverty volatility is particularly relevant to developing countries because these countries are exposed to shocks[3] that are persistent[4] (e.g., Aguiar and Gopinath, 2007) and whose frequency is higher than the frequency of shocks experienced by developed countries[5]. Such shocks can induce a strong variability of poverty rates - that is, significant fluctuations in poverty rates - in these countries, and as noted by Jefferson (2008), poverty variability is associated with the risk of poverty incidence. On another note, shocks in developing countries can significantly influence the dynamics of their fiscal policy (e.g., Böwer et al., 2007; Solimano and Calderon, 2017; Tanzi, 1986). This is exemplified for example, by the procyclical nature of fiscal policy in developing countries, i.e., expansionary fiscal policy in good times, and contractionary fiscal policy in bad times (e.g., Alesina et al., 2008; Calderón and Nguyen, 2016; Calderón et al., 2016; Ilzetski and Vegh; Talvi and Végh, 2005; Thornton, 2008). Talvi and Végh (2005) have suggested, in this regard, that the optimal policy for governments in developing countries can be to run procyclical fiscal policy when the tax base experiences large fluctuations due to exogenous shocks, given the significant costs of accumulating budget surpluses, and the related pressures to increase spending. According to the empirical findings by Strawczynski and Zeira (2013), the cycle observed in fiscal policy in developing countries is in reality a trend, given the persistence nature of the shocks that affect these economies. In this regard, tax revenue instability is of a key concern to policymakers, because it can result in greater public expenditure instability (e.g., Lim, 1983; Bleaney et al., 1995; Ebeke and Ehrhart, 2012), higher instability of both public investment and government consumption, and lower public investment level (e.g., Ebeke and Ehrhart, 2012) - all these lead ultimately to lower economic growth (e.g., Afonso and Furceri, 2010; Afonso and Jalles, 2012; Fatás and Mihov, 2013; Gong and Zou, 2002).

The current paper is essentially empirical, and aims to investigate the effect of poverty volatility on tax revenue instability. In so doing, it envisages to contribute both to the nascent literature on the effect of poverty volatility, and also to the literature on the macroeconomic determinants of tax revenue instability. To address this question, the empirical exercise uses an unbalanced panel dataset of 112 countries over the period 1980-2017, and the two-step system Generalized Methods of Moments (GMM) technique to address endogeneity concerns. Findings show that poverty volatility induces greater tax revenue instability in countries that experience a rising poverty rates.

In the rest of the paper, we provide in section 2, a theoretical discussion on how poverty volatility can affect tax revenue instability. We then present in Section 3 the model that allows to address the issue of the study. Section 4 discusses the econometric approach used to carry out the empirical analysis. Section 5 interprets empirical outcomes, and Section 6 concludes. 
[1] These goals were adopted at the Millennium Summit of the United Nations held at the United Nations headquarters in New York, on 8 September 2000.

[2] The 17 SDGs were adopted by the General Assembly of the United Nations, and contained in the document "Transforming our world: the 2030 Agenda for Sustainable Development", whose reference number is $\mathrm{A} / \mathrm{RES} / 70 / 1$.

[3] These shocks include environmental shocks such as natural disasters, political shocks (instability), as well as external shocks, including fluctuations in commodity prices and export demand, and volatile financial flows.

[4] Nevertheless, Narayan and Lu (2011) have considered whether shocks to ten commodity prices (gold, silver, platinum, copper, aluminium, iron ore, lead, nickel, tin, and zinc) are persistent. They have found that the persistence of shocks applies only to gold, silver, platinum, aluminium, and copper.

[5] See for example Ahuja et al., 2017; Álvarez et al., 2018; Brückner and Gradstein, 2013; Cariolle et al. 2016; Combes and Guillaumont (2002); Dabla-Norris and Gündüz (2014); Essers (2013); Guillaumont (2009, 2010, 2017); Guillaumont and Wagner (2012); Loayza et al. (2007); Mulder and Bussière (1999); Naoussi and Tripier (2013) and Seth and Ragab (2012).

\section{Theoretical Discussion On How Poverty Volatility Can Affect Tax Revenue Instability}

Low incomes negatively affect people's standard of life, consumption patterns and leisure time activities, and deteriorate their social relations and participation[1] (e.g., Callan et al. 1993; Mood and Jonsson, 2016; Mack and Lansley 1985). Poverty prevents people from enjoying a life in "decency" (Galbraith 1958). Compared to poor people in developed countries, poor individuals in developing countries are more averse to risk, and more likely to discount future payoffs than wealthier individuals (e.g., Haushofer and Fehr, 2014; Pender, 1996; Yesuf and Bluffstone, 2008).

Poverty deprives individuals from the requisite financial resources for investment in human capital, including physical capital and health (e.g., Azariadis and Stachurski, 2005; Bain et al. 2013; Bowles et al., 2006; Haushofer and Fehr, 2014; López, 2006; Perkins et al., 2012; Sachs, 2005). This adverse human capital effect of poverty is particularly enhanced when poor people have limited access to credit markets (e.g., Banerjee and Duflo, 2008; 2014; Carvalho et al., 2016). In this regard, Perry et al. (2006) have noted that the absence of a well-developed financial markets enhances the negative investment and economic growth effects of poverty. All these contribute to constraining investments in the economy, result in a less productive workforce (e.g., Breunig and Majeed, 2020; Hill and Sandfort, 1995), and ultimately hurt economic growth. Ravallion (2002) has shown that poverty reduces consumption growth, and leads to a less poverty-reducing economic growth. Ravallion (2012) and López and Servén (2015) have uncovered 
that a higher initial incidence of poverty tends to be associated with lower subsequent. Recently, Nakabashi (2018) has found that poverty incidence helps explain the weak performance in terms of economic development of the Brazilian States. This negative effect of poverty on economic development takes place through various channels, including malnourishment that retards child development, lower gray matter volume that leads to lower human capital accumulation, inefficiency increases due to resource misallocation, and lower fertility rate (Sinding, 2009).

Overall, poverty hurts economic growth through a variety of channels, including for example, lower investments in human capital accumulation, inefficient allocation of resources, lower consumption, and lower productivity. At the same time, all these factors of economic growth contribute to determining the breadth of a country's tax base (e.g., Besley and Persson, 2014). Against this background, we argue that poverty volatility would induce the volatility of the tax base elements, and consequently lead to the instability of tax revenue. For example, higher poverty volatility could translate into the volatility of domestic consumption as well as the volatility of imports, which could lead respectively to a greater volatility of indirect tax revenue (notably the volatility of the value-added tax (VAT) revenue) and a higher volatility of import tariff revenue. Similarly, the decline in the productivity associated with a rise in the poverty rate can translate into lower performance of firms in which poor people work, and result in lower corporate income for these firms. As a result, ups and downs movements of poverty rates can be associated with an instability of the corporate income tax revenue, and generate a higher instability of direct tax revenue. Similarly, a rise in poverty volatility that arises from a sudden and significant decline of people's income would shrink the personal income tax base, and trigger the instability of direct tax revenue. More generally, higher poverty volatility would generate greater fluctuations of the tax base, and potentially induce greater instability of tax revenue.

Notwithstanding this, we also postulate that poverty volatility would be associated with greater tax revenue instability, in particular if the rise in poverty variability took place in the context of an increase in the poverty level (i.e., poverty rate), or in other words, when there is a positive variation of poverty rates. This is because, in such a case, the instability of the tax base would inevitably reflect a shrink of the tax base, and hence a decline in tax revenue. In contrast, when the rise in poverty volatility reflects a sudden decline in poverty rates (due for example, to a positive external shock on economic growth, such as a rise in commodity price for an exporting commodity country), it might not necessarily result in a greater tax revenue instability because several factors may limit the government's ability to collect tax revenue, and generate higher tax revenue (compared to the tax revenue share in the period preceding the occurrence of the positive shock). In fact, Besley and Persson (2014: page 112) have noted that "even though economic growth is important in widening the tax net and increasing the tax base, it does not mechanically translate into a higher tax take". These authors have highlighted a number of potential factors that can explain the constraints to taxation - and hence stifle the collection of tax revenue - in developing countries (see Besley and Persson, 2014: page 100). These factors include the economic structure of economies; political factors (such as weak institutions and fragmented polities); a lack of transparency due to weak news media; and sociological and cultural factors (such as a weak sense of national identity and a poor norm for compliance). More importantly, Besley and Persson (2014) have underlined that the power to tax 
is at the core of state development, and is even more important than the capacity of the state to raise tax revenues: the state (through for example, its administrative capacity) needs to be capable of raising revenue, but also to furnish goods and services, to support a market economy, while ensuring participatory political systems where citizens would be able to demand a sound management of increasing public resources. Challenges facing by developing countries in raising tax revenue have also been discussed by other authors such as Carnahan (2015).

Summing-up, we expect poverty volatility to result in higher tax revenue instability in the context of rising poverty levels (i.e., higher poverty rates, or positive variations in poverty rates). However, poverty volatility might not significantly affect tax revenue instability, or may even be associated with lower tax revenue instability. This could be particularly the case if, for the reasons mentioned above, governments were not capable of raising tax revenue, further to a shock that positively affects the income of people (including poor ones), economic growth, and eventually lifts them out of poverty. The empirical analysis would help test these hypotheses.

[1] The negative externalities associated with higher poverty incidence have been highlighted by Galster et al. (2008).

\section{Empirical Model}

To analyse empirically the effect of poverty volatility on tax revenue instability, we rely on the limited previous works on the determinants of tax revenue instability (e.g., Lim, 1983; Bleaney et al., 1995; Ebeke and Ehrhart, 2012; Ebeke, 2014; Brun and Gnangnon, 2019; Gnangnon, 2020). We consider a baseline model specification in which the poverty volatility indicator is our main variable of interest, and where control variables include the economic growth volatility, the inflation volatility, the trade openness level, the real per capita income (as a proxy for the development level), and the institutional quality.

We consider the following model:

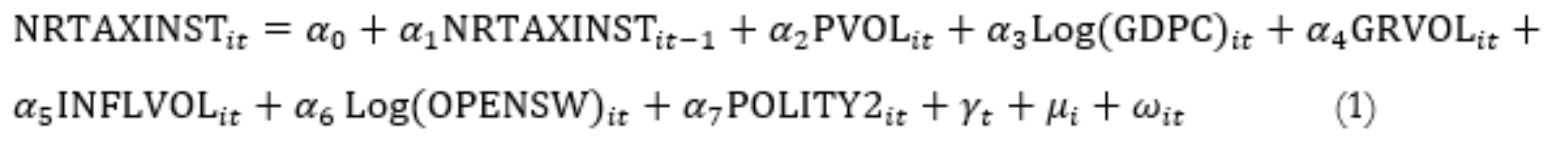

i represents a given country; and $t$ is the subscript associated with the time-period. The panel dataset used is unbalanced, and covers 112 countries over the period 1980-2017. to are estimates associated with each variable contained in model (1). are countries' time-invariant specific effects, and is a wellbehaving error term. are time dummies, which reflect global shocks affecting together all countries' tax revenue (and trigger tax revenue instability). We would like to note here that when included in the regression, none of these time dummies were statistically significant. Therefore, we have removed them from the regressions. Appendix 1 provides the description of all variables used in the analysis. 
Appendices 2 and 3 show respectively the descriptive statistics on these variables, and the list of the 112 countries.

The variables "NRTAXINST", "PVOL", "GRVOL" and "INFLVOL" are respectively the measures of tax revenue instability, poverty volatility, economic growth volatility, and inflation volatility. non-overlapping subperiods of 5-year have been used in the empirical analysis to compute the volatility variables. These subperiods include 1980-1984; 1985-1989; 1990-1994; 1995-1999; 2000-2004; 2005-2009; 2010-2014, and 2015-2017 (note that the last sub-periods covers only 3 years).

The dependent variable "NRTAXINST" represents the instability of the non-resource tax revenue (excluding grants and social contributions) in percentage of GDP. It is measured as the standard deviation of the annual growth rate of non-resource tax revenue (\% GDP) over each of the aforementioned nonoverlapping sub-periods. Non-resource tax revenue is computed as the difference between total tax revenue (excluding social contributions) in percentage of GDP, and tax revenue collected on natural resources, also expressed as a percentage of GDP. We have followed Gnangnon and Brun (2019), and used non-resource tax revenue (\% GDP) as the main indicator of tax revenue because excluding tax revenue on natural resources from total tax revenue helps to ensure the homogeneity in the tax revenue variable, across countries in the full sample (see also Brun et al., 2015).

Note that we also followed Brun and Gnangnon (2019), and Gnangnon (2020) by including in model (1), the variable capturing the terms of trade instability. However, the coefficient of the latter was never statistically significant, probably because of its correlation with both the trade openness variable and the inflation volatility indicator. Additionally, the inclusion of this variable in model (1) slightly reduces the size of the sample. Therefore, we have decided to remove the terms of trade instability variable from the analysis, as its inclusion does not change quantitatively and qualitatively the estimations' outcomes, but at the same time, reduces the size of the sample.

Following previous studies (e.g., Ebeke, 2014; Brun and Gnangnon, 2019; Gnangnon, 2020), we have introduced the one-period lag of the dependent variable as a regressor in model (1) so as to account for the persistence of the instability of tax revenue over time, and this helps, inter alia, to address the problems of omitted variables.

The computation of the poverty volatility variable "PVOL" rests on the use of two poverty indicators, namely poverty headcount ratio, and poverty gap rate. Here, we define the variable "POV" as the measure of poverty rate. The latter can be either the poverty headcount, that is, the $\$ 1.90$ a day, which represents the percentage of the population living with less than $\$ 1.90$ a day, at 2011 international prices (denoted "PHC"); or it can be the poverty gap at $\$ 1.90$ a day (2011 PPP), denoted "PGAP". The poverty gap reflects the depth and incidence of poverty. It represents the mean shortfall in income or consumption from the poverty line $\$ 1.90$ a day (counting the nonpoor as having zero shortfall), expressed as a percentage of the poverty line. Hence, our dependent variable "PVOL" can be measured using two indicators, including the volatility of poverty headcount ratio (denoted "PHCVOL") and the volatility of the poverty gap (denoted 
"PGAPVOL"). These two volatility variables have been calculated as the standard deviation of the annual growth of the relevant poverty indicator over each of the non-overlapping sub-periods of 5-year.

The economic growth volatility and inflation volatility have been computed respectively as the standard deviation of the economic growth rate, and the standard deviation of the inflation rate. The variable "OPENSW" and "POLITY2" that represent respectively the level of trade openness, and the degree of democratization in a given country (and acts in this regard, as a proxy for the institutional quality[1]), have been computed over the above-mentioned non-overlapping sub-periods of 5-year. In particular, we have followed Squalli and Wilson (2011) and compute the level of trade openness as the share of sum of exports and imports of goods and services in GDP, adjusted by the proportion of a country's trade level relative to the average world trade (see Squalli and Wilson, 2011: p1758). In contrast with the standard measure of trade openness used in the literature (which is the share of sum of exports and imports of goods and services in GDP), the proposed trade openness indicator by Squalli and Wilson (2011) provides a better picture on countries' level of integration into the world trade markets. In fact, the degree of a country's integration into the international trade market matters most (than a mere level of trade volume) for capturing this country's exposure to external shocks, and hence the possibility that these shocks could affect the country's economy, and trigger the instability of tax revenue. Finally, we have applied the natural logarithm to the variables "GDPC" and "OPENSW" in order to reduce their skewness.

We argue that the real per capita income would be negatively associated with tax revenue instability (see Gnangnon, 2020). This can be explained by the fact that advanced developing countries are more capable than relatively less advanced ones to cope with the effects of shocks on their economy (that would trigger tax revenue instability). For example, Gnangnon (2020) has reported a negative effect of the real per capita income on tax revenue instability. We also postulate that higher inflation volatility and higher economic growth volatility would induce greater tax revenue instability (e.g., Gnangnon and Brun, 2019; Ebeke, 2014; Gnangnon, 2020).

The effect of trade openness on tax revenue instability can be positive or negative (e.g., Gnangnon and Brun, 2019; Gnangnon, 2020). This effect can be negative if trade openness contributes to dampening the vulnerability of countries to idiosyncratic sectoral shocks through production and export diversification (e.g., Acemoglu and Zilibotti 1997; Haddad et al. 2011). In such a case, trade openness would contribute to mitigating the tax base fluctuations. The tax revenue instability effect of trade openness could be positive if greater trade openness led to a higher exposure of countries to external shocks. In this scenario, shocks affecting the economies would induce greater volatility of macroeconomic aggregate outcomes, such as aggregate income, consumption, employment, salaries, and prices (e.g., Ahmed and Suardi, 2009; di Giovanni and Levchenko, 2009; Kim et al., 2016). Gnangnon and Brun (2019) and Gnangnon (2020) have found a positive effect of trade openness on non-resource tax revenue instability. Ebeke (2014) has obtained, across his regressions, that trade openness can be associated positively with the instability of total tax revenue. Finally, following Gnangnon (2020), we anticipate that improvement in the institutional quality would help reduce the instability of tax revenue. This can take place through the role that a good performance in terms of institutions and governance could play in mitigating the 
negative effects of shocks (that would translate into greater tax revenue instability) on the economy. Even though the institutional quality variable was not the main variable of interest in the analysis by Gnangnon (2020), the latter has reported, across regressions, a tendency for no significant effect institutional and governance quality on non-resource tax revenue instability.

Before moving to the empirical part of the paper, we find useful to look at the development of poverty volatility indicators and the tax revenue instability indicator (see Figure 1). We note from this Figure that the degree of tax revenue instability has been declining over time, while at the same time, the two poverty indicators have strongly fluctuated over the period under analysis.

[1] A number of studies (e.g., Charron and Lapuente, 2010; Desbordes and Verardi, 2017; Guerin and Manzocchi, 2009; Rodrik, 1996) have underlined that the level of democracy in a country can be a proxy for institutional and governance quality in that country.

\section{Estimation Approach}

At the outset, we would like to note that all regressions presented below are performed using the two indicators of poverty volatility described above.

We start the empirical part of this paper by estimating two specifications of model (1) that excludes the one-period lag of the dependent variable as a regressor. To perform this estimation, we use the within fixed effect estimator ("FEDK"), where standard errors have been corrected using the Driscoll and Kraay (1998) approach. The outcomes of the estimation of these specifications of model (1) are provided in columns [1] and [2] of Table 1. However, as noted in the studies that have examined the macroeconomic determinants of tax revenue instability (e.g., Gnangnon and Brun, 2019; and Gnangnon, 2020), some regressors in model (1) are likely endogenous, with possible endogeneity concerns arising, inter alia, from the bi-directional causality between those regressors and the tax revenue instability variable. In the present analysis, we consider as endogenous the poverty volatility variables, and the variables capturing economic volatility, trade openness, and institutional quality. For example, the reverse causality from the dependent variable to the poverty variable can be explained by the fact that high instability of nonresource tax revenue would generate a greater instability of public expenditure, and may prevent governments from having stable stream of financial resources that would help to mitigate the adverse effects of shocks on their economies (and consequently to dampen the resulting strong volatility of poverty rates). The endogeneity of trade openness can be due to the fact that greater instability of tax revenue attributed to a greater level of trade openness can lead governments to adopt restrictive trade policies or other economic measures that would reduce their degree of trade openness. Policymakers might also be tempted to dampen the volatility of output/or the inflation volatility if they realized that these volatilities were sources of high tax revenue instability. Finally, countries aiming at stabilizing their 
tax revenue ratio can endeavour to put in place new institutions/ or enhance the performance of existing institutions that directly affect the mobilization of tax revenue (e.g., Bird et al., 2008; Ehrhart, 2012; Garcia and von Haldenwang, 2012).

Another endogeneity problem related to the estimation of the dynamic model (1) with standard econometric estimators such as the fixed effects estimator, stems from the correlation between the oneperiod lag of the dependent variable and the error term. This would generate important bias, referred to as Nickell bias (Nickell, 1986), whose magnitude diminishes as the time dimension of panel dataset increases. In the present analysis, this bias can be strong given the limited time-series dimension and the relatively larger cross-sectional dimension of our panel dataset.

To handle these endogeneity problems, we follow previous works (e.g., Gnangnon and Brun, 2019; Gnangnon, 2020; Ebeke, 2014) and utilize the two-step system GMM estimator suggested by Arellano and Bover (1995) and Blundell and Bond (1998). This estimator is particularly suitable for overcoming endogeneity concerns in dynamic panel datasets with limited time dimension, and relatively large crosssections. Moreover, it is more efficient than the difference GMM estimator proposed by Arellano and Bond (1991) (e.g., Bond et al., 2001) as the latter can generate weak instruments. Additionally, in contrast with the two-step system GMM estimator, the difference GMM approach magnifies problems of unbalanced panels in dynamic panel dataset (Roodman, 2009). The use of the two-step system GMM estimator involves estimating a system of equations (i.e., level and first difference equations), where appropriately lagged first differences are used as instruments for the level equation, and appropriate lagged levels are used as instruments for the first-difference equation. We assess the consistency of this estimator by relying on several diagnostic tests that include the Arellano-Bond test of the presence of first-order serial correlation in the error term (denoted AR(1)); the Arellano-Bond test of the absence of second-order autocorrelation in the error term (denoted AR(2)); and the Sargan/Hansen test of over-identifying restrictions (OID). Using the null hypothesis that the instruments used in the regressions are exogenous, the OID test helps evaluate the exogeneity of instruments as well as the existence of the 'too many instruments' problem (or instrument proliferation). We have also presented the results of the ArellanoBond test of absence of third-order autocorrelation in the error term (denoted AR(3)): the absence of autocorrelation at the third-order autocorrelation in the error term may be an indication of the absence of omitted variables in the model. Also, following the practice in the empirical literature, we have reported the number of instruments used in the regressions, as a higher number of instruments than the number of countries would weaken the powerfulness of the above-mentioned tests (e.g., Roodman, 2009). To meet all requirements for the two-step system GMM estimator described above, the regressions described below have used 3 lags of the dependent variable as instruments, and 2 lags of endogenous variables as instruments.

We now turn to the description of different specifications of model (1) estimated using the two-step system GMM estimator. Columns [4] and [5] of Table 1 report the estimates arising from the estimation of the dynamic model (1), i.e., model (1) as it stands. In the second instance, we investigate whether the effect of poverty volatility on tax revenue instability varies across countries in the full sample. In light with 
our hypothesis concerning the effect of poverty volatility on tax revenue instability (see Section 2), we postulate here that poverty volatility would result in a lower tax revenue instability in advanced developing countries than in less advanced ones. We perform this empirical analysis by running regressions of model (1) (i.e., with each of the two poverty volatility indicators) that contain the interaction between the poverty volatility indicator and the real per capita income variable. The results of these regressions are presented in Table 2.

Estimation's outcomes presented in Table 3 allow assessing whether the effect of poverty volatility on tax revenue instability is conditional upon the prevailing level of poverty rate, and more importantly the size of the variation in the poverty rates. To obtain these outcomes, we estimates different specifications of model (1) that is, with each indicator of poverty volatility (and the associated poverty rate/or growth of poverty rate). These involve model (1) in which we have introduced the poverty rate variable (i.e., "PHC" or "PGAP") / or the growth rate of poverty rate (i.e., "GRPHC", or "GRPGAP") along with its interaction with the relevant poverty volatility indicator. Note that in all specifications of model (1) whose results are presented in Table 3, we have considered poverty indicators as well as their growth rate as endogenous.

\section{Empirical Outcomes}

In this section, we use the expression "tax revenue instability" to refer to "non-resource tax revenue instability". Starting with the results in columns [1] and [2] of Table 1 (i.e., results based on the FEDK estimator), we find no significant effect (at the conventional levels) of poverty volatility indicators (both poverty headcount rate volatility and poverty gap volatility) on tax revenue instability. At the same time, many regressors show significant coefficients. We obtain, as expected, that at the $1 \%$ level, tax revenue instability is positively driven by higher economic growth volatility and higher inflation volatility. Additionally, real per capita income is negatively and significantly (at the $1 \%$ level) associated with tax revenue instability. However, trade openness appears to be negatively associated with tax revenue instability (at the $5 \%$ level). Finally, at the conventional levels, the institutional quality exerts no significant effect on tax revenue instability.

As underlined above, these outcomes might be biased, and hence the need for considering estimates based on the two-step system GMM estimator, that are reported in columns [3] and [4] of Table 1 and in Tables 2 and 3. We first note from these Tables that the one-period lag of the dependent variable always exhibits a positive and significant coefficient at the $1 \%$ level. This confirms the persistence nature of tax revenue instability, and thus, the necessity to consider model (1) in a dynamic setting. Second, we observe that we cannot reject the null hypotheses of Arellano-Bond tests of first, second and third-order autocorrelations in the error term. This is because the p-values related to the AR(1) test are always zero, i.e., lower than 0.1 ( $10 \%$ level of statistical significance), while the p-values of the $A R(2)$ and $A R(3)$ tests are all higher than 0.1 (10\% level of statistical significance). Incidentally, the p-values of the OID test are all higher than 0.10, and we obtain across all Tables that the number of instruments is lower than the number of countries. Building on these results, we conclude that the two-step system GMM estimator is appropriate for conducting the empirical analysis.

Page $11 / 33$ 
We now consider the estimates presented in columns [3] and [4] of Table 1. We note from these two columns that the coefficients of the two poverty volatility indicators are all significant at the $1 \%$ level and are additionally similar, as they amount to 0.103 and 0.105 respectively for poverty headcount volatility and poverty gap volatility. These outcomes are clearly different from those based on the FEDK estimator. Here, a 1 percentage increase in the level of poverty headcount volatility is associated with a 0.103 percentage fall in tax revenue instability. Similarly, a 1 percentage increase in the level of poverty gap volatility is associated with a 0.105 percentage decline in tax revenue instability. We would conclude that over the full sample, poverty volatility is associated with lower tax revenue instability. However, these outcomes might seem contradictory with our theoretical hypothesis, but they are in fact not. First, these results represent average effects across countries in the full sample, and surely hide differentiated effects across countries. Second, as postulated above, the effect of poverty volatility on tax revenue instability is likely to be dependent on the poverty level (or more importantly on the size of the variation in poverty rates). Before turning to estimates reported in Tables 2 and 3 that help test these hypotheses, we first interpret the estimates related to control variables in columns [4] and [5]. These estimates in the two columns are quite similar, both in terms of the magnitude of effects, and statistical significance of the coefficients. Specially, at the $5 \%$ level, tax revenue instability is positively driven by higher economic growth volatility, higher inflation volatility, and lower level of democracy. Trade openness and the real per capita income do not affect significantly tax revenue instability at the conventional levels.

Turning now to results in Table 2, we find that the interaction terms associated with the interaction variable between each poverty volatility indicator and the real per capita income (in the two columns of this Table), are negative and significant at the $1 \%$ level. These suggest that the effect of poverty volatility on tax revenue instability depends on countries' real per capita income level, and particularly decreases as countries experience a higher real per capita income. At the same time, the coefficient of the variable "Log(PHCVOL)" is positive and significant at the 1\% level, while that of "Log(PGAPVOL)" is positive and significant at the $5 \%$ level. Based on these outcomes, we deduce that there is a turning point of the real per capita income above which the total effect of poverty volatility on tax revenue instability becomes negative (as below this threshold, the effect is positive). This threshold of the real per capita income amounts to US\$1253.2 [= exponential $(0.433 / 0.0607)$ ] for the outcomes based on the poverty headcount rate volatility, and US\$ 593.69 [= exponential $(0.281 / 0.0440)]$ for the outcomes based on the poverty gap. It, therefore, appears that poverty volatility tends to be associated with higher tax revenue instability in relatively low income countries (that is, those with real per capita income lower than US\$ 1253.2 when we use poverty headcount rate volatility as the measure of poverty volatility), and very low-income countries (i.e., poorest countries, with real per capita income lower than US\$ 593.69 when we use poverty gap volatility as the measure of poverty volatility). However, in relatively advanced countries (i.e., those with a real per capita income higher than US\$ 1253.2 when we consider poverty headcount rate volatility as the measure of poverty volatility, or higher than US\$ 593.69 when we use poverty gap volatility as the measure of poverty volatility), poverty volatility is associated with lower tax revenue instability. For these relatively advanced countries, the higher the real per capita income, the greater is the magnitude of the negative effect of poverty volatility on tax revenue instability. While these outcomes concerning relatively 
advanced countries say nothing about the extent to which the tax revenue instability effect of poverty volatility varies for various poverty rates (or variation in poverty rates), they may have an interpretation. One interpretation can be that low-income countries (i.e., poor countries) exhibit higher poverty rates than other developing countries; as noted above, they are likely more prone to shocks (that could trigger significant rise in poverty rates and hence poverty volatility) than advanced developing countries, and have lesser human resources and financial means to cope with such shocks compared to other developing countries. As a result, they are likely to experience a higher positive effect of poverty volatility on tax revenue instability than relatively advanced countries. In fact, in the event of adverse shocks, and even if the latter temporarily translate into higher poverty volatility, policymakers of relatively advanced developing countries might be willing to limit the fluctuations of the tax base. This could be done by eventually enhancing/or developing well social safety nets schemes for poor people, and/or by enhancing redistributive policies, including through for example, well-targeted transfers and well-design tax policy. In particular, in the case of negative shocks that induce a high poverty volatility, policymakers of relatively advanced developing countries may reduce benefits (for example, tax exemptions) that accrued to richer people before the shocks), or even increase the tax rates on richer people, so as to collect higher tax revenue. This could more than offset the fall in tax revenue that can arise from the rise in poverty rates (i.e., the rise in poverty rates could lead to a fall in the tax revenue collected from those poor people - whose income has declined, and who consume and invest less now).

Results of control variables in Table 2 are consistent with those in columns [3] and [4] of Table 1.

Estimates presented in columns [1] and [2] of Table 3 show that the coefficients of the variables "Log(PHCVOL)" and "Log(PHCVOL)" are negative and significant at the 1\% level, while at the same time, the interaction between each of these variables and the relevant poverty volatility indicator show positive, and statistically significant coefficients (at the $1 \%$ level). These outcomes, therefore, confirm our hypothesis set out in Section 2 that the effect of poverty volatility on tax revenue instability genuinely increases as the level of poverty rate rises. However, it appears that poverty volatility does not result in higher tax revenue instability for all levels of poverty rates: there is in fact a threshold of poverty rate above which poverty volatility induces a greater instability of tax revenue. This threshold is 46.47 (= $0.0990 / 0.00213)$ for poverty headcount ratio, and $19.06(=0.122 / 0.00640)$. It is worth recalling that values of poverty headcount ratio range between 0.008 and 94.4 , and those of the poverty gap indicator range between 0 and 64.5. Based on these outcomes, we conclude, for the estimates based on the poverty headcount ratio, that countries whose level of poverty headcount rate is lower than 46.5 enjoy a negative effect of poverty volatility on tax revenue instability: for these countries, the lower the poverty rates, the greater is the magnitude of the negative effect of poverty headcount volatility on tax revenue instability. In contrast, countries whose poverty headcount rate is higher than 46.5 experience a positive effect of poverty volatility on tax revenue instability, and for this group of countries, the higher the poverty rates, the greater is the magnitude of the positive effect of poverty headcount volatility on tax revenue instability. The same reasoning applies to the estimates related to the poverty gap, with the exception that here, the turning point of poverty gap rate amounts to 19.1. The main message from columns [1] and [2] 
of Table 3 is that higher poverty volatility induces higher tax revenue instability in the context of rising poverty rates, notably if the latter exceed a certain threshold.

Results in columns [3] and [4] of Table 3 confirm the findings in columns [1] and [2] of the same Table. Here, the coefficients of both "([Log(PHCVOL)]*[GRPHC])" and "([Log(PGAPVOL)]*[GRPGAP])" are positive and significant at the $1 \%$ level, whereas those of the variables "([Log(PHCVOL)])" and "([Log(PGAPVOL])" are negative and significant at the $1 \%$ level. These suggest that there is a turning point of the growth of poverty rates above which the effect of poverty volatility on tax revenue instability becomes positive. The turning point for the growth of the poverty headcount rate is $3.16(=0.135 / 0.0427)$ and the one for the growth of the poverty gap is $1.97(=0.0774 / 0.0392)$. These turning points are well lower than the maximum value of the growth rate of the poverty headcount (which is 12.4) and the maximum value of the growth rate of the poverty gap (which is 30.98) (see Appendix 2). Thus, above these thresholds of the growth rate of poverty, poverty volatility induces greater instability of tax revenue, and the higher the growth rate of poverty, the greater is the magnitude of the positive effect of poverty volatility on tax revenue instability. The take-home message of results in columns [3] and [4] of Table 3 is that poverty volatility induces a higher positive effect on tax revenue instability in countries that experience an increase in the growth of poverty rates. Once again, estimates of control variables are largely consistent with those reported in columns [3] and [4] of Table 1.

\section{Conclusion}

This paper explores the effect of poverty volatility on tax revenue instability using a sample of 112 developing countries, and relying on the two-step system GMM technique. The findings indicate that poverty volatility enhances tax revenue instability in low-income countries, while it reduces the instability of tax revenue in relatively advanced developing countries. This result is likely explained by the prevalence of higher poverty rates in low-income countries (or poor countries) than in other developing countries. This is confirmed by our empirical finding that the effect of poverty volatility on tax revenue instability depends on the poverty rate, as well as the size of the variation in the poverty rates. Specially, poverty volatility induces greater instability of tax revenue in the context of rising poverty rates, and in particular when the latter exceed a certain level. These outcomes show that poverty volatility definitely matters for tax revenue instability: in light of the adverse effects of tax revenue instability on public expenditure volatility and economic growth, policymakers should take this important outcome into account when designing policies to both raise tax revenue and ensuring its stability. Developing countries face many challenges in raising tax revenue, even in the context of higher economic growth rate (e.g., Besley and Persson, 2014; Carnahan, 2015). However, even though they might not be able to raise tax revenue in a way consistent with the potential tax revenue level, they should ensure the stability of tax revenue so as to be able to continuously supply the requisite public goods and services to the population, including to poor ones, and finance many other development needs. The present analysis has shown that one way to do so is to implement policies and develop institutions conducive to poverty reduction, but also those that ensure that further to negative shocks, poverty rates do not suddenly increase. Such a strategy might involve developing social safety nets, and put in place appropriate redistributive policies, 
including for example, well-targeted transfers and taxes that would help cushion negative consequences of adverse shocks on poverty (that ultimately result in higher poverty volatility).

\section{Declarations}

\section{Disclaimer:}

This is a working paper, which represents the personal opinions of individual staff members and is not meant to represent the position or opinions of the WTO or its Members, nor the official position of any staff members. Any errors or omissions are the fault of the author.

\section{Competing interests:}

The author declares no competing interests

\section{References}

Acemoglu, D., Johnson, S., Robinson, J., and Thaicharoen, Y. (2003). Institutional causes, macroeconomic symptoms: Volatility, crises and growth. Journal of Monetary Economics, 50(1), 49-123.

Afonso, A., and Furceri, D. (2010). Government Size, Composition, Volatility and Economic Growth. European Journal of Political Economy, 26(4), 517-532.

Afonso, A., and Jalles, J. T. (2012). Fiscal volatility, financial crises and growth, Applied Economics Letters, 19(18), 1821-1826.

Aguiar, M., and Gopinath, G. (2007). Emerging Markets Business Cycles: The Cycle is the Trend. Journal of Political Economy, 115(1), 11-69.

Ahmed, A.D., and Suardi, S. (2009). Macroeconomic Volatility, Trade and Financial Liberalization in Africa. World Development, 37(10), 1623-1636. 
Ahuja, A., Syed, M., and Wiseman, K. (2017). Assessing Country Risk - Selected Approaches - Reference Note. Technical Notes and Manuals 17/08, International Monetary Fund, Washington, D.C.

Alesina, A., Campante, F.R., and Tabellini, G. (2008). Why is Fiscal Policy Often Procyclical? Journal of the European Economic Association, 6(5), 1006-1036.

Alesina, A., Campante, F.R., and Tabellini, G. (2008). Why is Fiscal Policy Often Procyclical? Journal of the European Economic Association, 6(5), 1006-1036.

Álvarez, R., García-Marín, A., llabaca, S. (2018). Commodity price shocks and poverty reduction in Chile. Resources Policy, See online at: https://doi.org/10.1016/j.resourpol.2018.04.004

Arellano, M. and Bover, O. (1995). Another look at the instrumental variable estimation of errorcomponents models. Journal of Econometrics 68 (1), 29-51.

Arellano, M., and Bond, S. (1991). Some Tests of Specification for Panel Data: Monte Carlo Evidence and an Application to Employment Equations. Review of Economic Studies, 58, 277-297.

Azariadis, C., and Stachurski, J. (2005). Poverty traps. In: Philippe Aghion \& Steven Durlauf (ed.), Handbook of Economic Growth, edition 1, volume 1, chapter 5, Elsevier.

Bagchi, S., and Svejnar, J. (2015). Does wealth inequality matter for growth? The effect of billionaire wealth, income distribution, and poverty. Journal of Comparative Economics, 43(3), 505-530.

Bain, L.E., Awah, P.K., Geraldine, N., Kindong, N.P., Siga, Y., Bernard, N., and Tanjeko, A.T. (2013).

Malnutrition in sub-saharan africa: burden, causes and prospects. Pan African Medical Journal 15 (120). 
Banerjee, A. V., and Duflo, E. (2008). What is middle class about the middle classes around the world? Journal of Economic Perspectives, 22(2), 3-28.

Banerjee, A., and Duflo, E. (2014). Do firms want to borrow more: Testing credit constraints using a targeted lending program. Review of Economic Studies, 81, 572-607.

Banerjee, A.V., and Newman, A. (1993). Occupational choice and the process of development. Journal of Political Economy, 101(2), 274-298.

Barrett, C.B., and Carter, M.R. (2013). The economics of poverty traps and persistent poverty: empirical and policy implications. Journal of Development Studies, 49, 976-990.

Barrett, C.B., Garg, T., and McBride, L. (2016). Well-being dynamics and poverty traps. Annual Review of Resource Economics, 8(1), 303-327.

Besley, T., and Persson, T. (2014). Why Do Developing Countries Tax So Little? Journal of Economic Perspectives, 28(4), 99-120.

Bird, R. M., Martinez-Vazquez, J. and Torgler, B. (2008). Tax Effort in Developing Countries and HighIncome Countries: The Impact of Corruption, Voice and Accountability, Economic Analysis and Policy, $38(1), 55-71$.

Bleaney, M., Gemmell, N., and Greenaway, D. (1995). Tax revenue instability, with particular reference to Sub-Saharan Africa. Journal of Development Studies, 31, 883-902.

Blundell, R., and Bond, S. (1998). Initial Conditions and Moment Restrictions in Dynamic Panel Data Models. Journal of Econometrics, 87(1), 115-143.

Böwer, U., Geis, A., and Winkler, A. (2007). Commodity price fluctuations and their impact on monetary and fiscal policies in Western and Central Africa. Occasional Paper Series 60, European Central Bank. 
Bowles, S., Durlauf, S., and Hoff, K. (2006). Poverty Traps. Russell Sage Foundation. Princeton University Press, Princeton, NJ.

Breunig, R., and Majeed, O. (2020). Inequality, poverty and economic growth. International Economics, 161, 83-99.

Brückner, M., and Gradstein, M. (2013). Effects of transitory shocks to aggregate output on consumption in poor countries. Journal of International Economics, 91(2), 343-357.

Brun J.F., Chambas, G., and Mansour, M. (2015). "Tax Effort of Developing Countries: An Alternative Measure", In: Financing Sustainable Development Addressing Vulnerabilities, Chapter 11. Edited by Boussichas, M., and Guillaumont, P., Economica. FERDI.

Calderón, C., and Nguyen, H. (2016). The Cyclical Nature of Fiscal Policy in Sub-Saharan Africa. Journal of African Economies, 25(4), 548-579.

Calderón, C., Duncan, R., and Schmidt-Hebbel, K. (2016). Do Good Institutions Promote Countercyclical Macroeconomic Policies? Oxford Bulletin of Economics and Statistics, 78(5), 650-670.

Callan, T., Nolan, B., and Whelan, C. T. (1993). Resources, deprivation, and the measurement of poverty. Journal of Social Policy, 22, 141-172.

Cariolle, J., Goujon, M., and Guillaumont, P. (2016). Has Structural Economic Vulnerability Decreased in Least Developed Countries? Lessons Drawn from Retrospective Indices. The Journal of Development Studies, 52(5), 591-606.

Carnahan, M. (2015). Taxation Challenges in Developing Countries. Asia \& the Pacific Policy Studies, 2(1), 169-182. 
Carvalho, L., Meier, S., and Wang, S. W. (2016). Poverty and economic decision making: evidence from changes in financial resources at payday. American Economic Review, 106(2), 260-84.

Charron, N., and Lapuente, V. (2010). Does democracy produce quality of government? European Journal of Political Research, 49(4), 443-470.

Combes, J-L., and Guillaumont, P. (2002). Commodity Price Volatility, Vulnerability and Development. Development Policy Review, 20(1), 25-39.

Dabla-Norris, E., and Gündüz, Y. B. (2014). Exogenous Shocks and Growth Crises in Low-Income Countries: A Vulnerability Index. World Development, 59, 360-378.

Desbordes, R., and Verardi, V. (2017). Foreign Direct Investment and Democracy: A Robust Fixed Effects Approach to a Complex Relationship. Pacific Economic Review, 22(1), 43-82.

di Giovanni, J., and Levchenko, A. A. (2009). Trade openness and volatility. Review of Economics and Statistics, 91(3), 558-585.

Dreher, A. (2006). Does globalisation affect growth? Evidence from a new index of globalisation. Applied Economics, 38(10), 1091-1110.

Driscoll, J. C., and Kraay, A.C. (1998). Consistent Covariance Matrix Estimation with Spatially Dependent Panel Data. Review of Economics and Statistics, 80 (4), 549-560.

Ebeke, C., and Ehrhart, H. (2012). Tax Revenue Instability in Sub-Saharan Africa: Consequences and Remedies. Journal of African Economies, 21(1), 1-27.

Ebeke, C.H. (2014). Do International Remittances affect the level and the volatility of government tax revenue? Journal of International Development, 26(7), 1039-1053. 
Ehrhart, E. (2012). Assessing the relationship between democracy and domestic taxes in developing countries. Economics Bulletin, 32(1), 551-566.

Essers, D. (2013). Developing country vulnerability in light of the global financial crisis: Shock therapy? Review of Development Finance, 3(2), 61-83.

Fatás, A., and Mihov, I. (2013). Policy Volatility, Institutions, and Economic Growth. The Review of Economics and Statistics 2013 95(2), 362-376.

Galbraith, J. (1958). The affluent society. Boston: Houghton-Mifflin.

Galster, G.C., Cutsinger, J., Malega, R. (2008). The costs of concentrated poverty: neighborhood property markets and the dynamics of decline. In:Retsinas, N., Belsky, E. (Eds.), Revisiting Rental Housing. Brookings Institution Press, Washington, D.C, pp. 93-113.

Garcia, M.M., and von Haldenwang, C. (2012). Do Democracies Tax More? Political Regime Type and Taxation. Journal of International Development, 28(4), 485-506.

Gnangnon, S. K. (2019a). Poverty and export product diversification in developing countries. Journal of International Trade \& Economic Development, 29(2), 211-236.

Gnangnon, S. K. (2019b). Do Poverty Rates matter for the degree of Trade Openness in Developing Countries? Journal of International Commerce, Economics and Policy, see online at: https://doi.org/10.1142/S1793993320500052

Gnangnon, S.K. (2020). General Budget Support and Tax Revenue Instability in Developing Countries. International Economic Journal, 34(3), 405-425. 
Gnangnon, S.K., and Brun, J-F. (2019b). Tax Reform and Public Revenue Instability in Developing Countries: Does the Volatility of Development Aid Matter? Journal of International Development, 31(8), 764-785.

Gong, L., and Zou, H-F. (2002). Effects of Growth and Volatility in Public Expenditures on Economic Growth: Theory and Evidence. Annals of Economics and Finance, 3(2), 379-406.

Guerin, S. S., and Manzocchi, S. (2009). Political regime and FDI from advanced to emerging countries. Review of World Economics, 145(1), 75-91.

Guillaumont, P. (2009). An economic vulnerability index: its design and use for international development policy. Oxford Development Studies, 37(3), 193-228.

Guillaumont, P. (2010). Assessing the Economic Vulnerability of Small Island Developing States and the Least Developed Countries. Journal of Development Studies, 46(5), 828-854.

Guillaumont, P. (2017). Vulnerability and Resilience: A Conceptual Framework applied to Three Asian Countries - Bhutan, Maldives, and Nepal. ADB South Asia Working Paper Series N53, Asian Development Bank, Philippines.

Guillaumont, P., and Wagner, L. (2012). Aid and Growth Accelerations - Vulnerability Matters. UNU-WIDER Working Paper No. 2012/31. UNU World Institute for Development Economics Research (UNU-WIDER), Helsinki, Finland

Gygli, S., Haelg, F., Potrafke, N., and Sturm, J-E. (2019). The KOF Globalisation Index - Revisited. Review of International Organizations, 14, 543-574.

Haddad, M., Lim J. J., Munro L., Saborowski C., and Shepherd B. (2011). Volatility, Export, Diversification, and Policy", Chapter 11, In Managing Openness: Trade and Outward-Oriented Growth after the Crisis. 
World Bank, Washington, D.C.

Haushofer, J., and Fehr, E. (2014). On the Psychology of Poverty. Science, 344(6), 862-867.

Hill, M. S., and Sandfort, J. R. (1995). Effects of childhood poverty on productivity later in life: Implications for public policy. Children and Youth Services Review, 17(1-2), 91-126.

Jefferson, P. N. (2008). Poverty Volatility and Macroeconomic Quiescence. American Economic Review, 98(2), 392-397.

Kim, D-H., Lin, S-C., and Suen, Y-B. (2016). Trade, growth and growth volatility: New panel evidence. International Review of Economics \& Finance, 45, 384-399.

Lim, D. (1983). Instability of Government Revenue and Expenditure in Less Developed Countries. World Development, 11(5), 447-50.

Loayza, N.V., Rancière, R., Servén, L., and Ventura, J. (2007). Macroeconomic Volatility and Welfare in Developing Countries: An Introduction. The World Bank Economic Review, 21(3), 343-357.

López, H. (2006). Does poverty matter for growth. In: Perry, G.E., Arias, O.S., López, J.H., Maloney, W.F., Servén, L. (Eds.), Poverty Reduction and Growth: Virtuous and Vicious Circles. World Bank Publications, Washington, DC, pp. 103-128. chapter 6.

López, H., and Servén, L. (2015). "Too Poor to Grow," Central Banking, Analysis, and Economic Policies Book Series, in: Ricardo J. Caballero \& Klaus Schmidt-Hebbel (ed.),Economic Policies in Emerging-Market Economies Festschrift in Honor of Vittorio Corbo, edition 1, volume 21, chapter 13, pages 309-350, Central Bank of Chile.

Mack, J., and Lansley, S. (1985). Poor Britain. London: Allen \& Unwin Ltd. 
Marshall, M.G., Gurr, T.R., and Jaggers, K. (2018). Polity IV Project: Political Regime Characteristics and Transitions, 1800-2017. Centre for Systemic Peace: Vienna, VA.

Mehanna, R. A. (2004). Poverty and economic development: not as direct as it may seem. The Journal of Socio-Economics, 33(2), 217-228.

Mirza, M. U., Richter, A., van Nes, E.H., and Scheffer, M. (2019). Technology driven inequality leads to poverty and resource depletion. Ecological Economics, 160, 215-226.

Mood, C., and Jonsson, J.O. (2016). The Social Consequences of Poverty: An Empirical Test on Longitudinal Data. Social Indicators Research, 127, 633-652.

Mulder, C.B., and Bussière, M. (1999). Political Instability and Economic Vulnerability. IMF Working Paper No. 99/46. International Monetary Fund, Washington, D.C.

Nakabashi, L. (2018). Poverty and economic development: Evidence for the Brazilian states. EconomiA, $19,445-458$.

Naoussi, C.F., and Tripier, F. (2013). Trend shocks and economic development. Journal of Development Economics, 103, 29-42.

Narayan, P.K., and Lu, R. (2011). Are shocks to commodity prices persistent? Applied Energy, 88(1), 409416.

Nickell, S. (1981). Biases in Dynamic Models with Fixed Effects. Econometrica, 49(6), 1417-1426.

Pender, J. L. (1996). Discount rates and credit markets: Theory and evidence from rural India. Journal of Development Economics, 50(2), 257-296. 
Perkins, D.H., Radelet, S., Lindauer, D.L., Block, S.A. (2012). Economics of Development. W.W. Norton, New York, NY.

Perry, E. G., Arias, O. S., López, J.H., Maloney, W.F., and Servén, L. (2006). Poverty Reduction and Growth: Virtuous and Vicious Circles. World Bank Publications 35348, Washington, DC.

Ravallion, M. (2002). Why don't we see poverty convergence? American Economic Review, 102 (1), 504523.

Ravallion, M. (2012). Why don't we see poverty convergence? American Economic Review, 102 (1), 504523.

Rodrik, D. (1996). Understanding economic policy reform. Journal of Economic Literature, 34(1), 9-41.

Roodman, D. M. (2009). A note on the theme of too many instruments, Oxford Bulletin of Economic and Statistics, 71 (1), 135-158.

Sachs, J. (2005). The End of Poverty: How We Can Make it Happen in Our Lifetime. Penguin Group, London, UK.

Santos-Paulino, A.U. (2017). Estimating the impact of trade specialization and trade policy on poverty in developing countries, The Journal of International Trade and Economic Development, 26(6), 693-711.

Seth, A., and Ragab, A. (2012). Macroeconomic vulnerability in developing countries: Approaches and issues, Working Paper, No. 94, International Policy Centre for Inclusive Growth (IPC-IG), Brasilia. 
Sinding, S.W. (2009). Population, poverty and economic development. Philosophical Transactions of the Royal Society B, 364, 3023-3030.

Solimano, A., and Calderón, D. (2017). The copper sector, fiscal rules, and stabilization funds in Chile. UNU-WIDER Working Paper, 2017/53, Helsinki.

Squalli, J., and Wilson, K. (2011). A New Measure of Trade Openness. The World Economy, 34(10), 17451770.

Strawczynski, M., and Zeira, Y. (2011). "Procyclicality of fiscal policy in emerging countries: the cycle is the trend", Fiscal Policy and Macroeconomic Performance, Edited by J. Gali and L.F. Cespedes, edition 1, volume 17, chapter 11, pages 427-466, Central Bank of Chile, Chile.

Tanzi, V. (1986). Fiscal Policy Responses to Exogenous Shocks in Developing Countries. The American Economic Review, 76(2), 88-91.

Thornton, J. (2008). Explaining Procyclical Fiscal Policy in African Countries. Journal of African Economies, 17(3), 451-464.

Yesuf, M., and Bluffstone, R. (2008). Wealth and Time Preference in Rural Ethiopia, Environment for Development Discussion Paper No. EfD DP 08-16 (2008), Gothenburg, Sweden.

Yeyati, E. L., Panizza U, and Stein, E (2007). The cyclical nature of North-South FDI flows. Journal of International Money and Finance, 26, 104-130.

\section{Tables}

Table 1: Effect of Poverty volatility on Non-resource tax revenue instability Estimators. FE and Two-Step System GMM 
Page 26/33 


\begin{tabular}{|c|c|c|c|c|}
\hline \multicolumn{3}{|c|}{ FE } & \multicolumn{2}{|c|}{ Two-Step System GMM } \\
\hline Variables & Log(NRTAXINST) & Log(NRTAXINST) & Log(NRTAXINST) & Log(NRTAXINST) \\
\hline & (1) & (2) & (3) & (4) \\
\hline \multirow{2}{*}{$\begin{array}{l}\log (\text { NRTAXINST) })_{-} \\
1\end{array}$} & & & 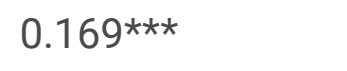 & $0.189 * * *$ \\
\hline & & & $(0.0296)$ & $(0.0323)$ \\
\hline \multirow[t]{2}{*}{ Log(PHCVOL) } & 0.0305 & & $-0.103^{\star \star \star}$ & \\
\hline & $(0.0202)$ & & $(0.0317)$ & \\
\hline \multirow[t]{2}{*}{ Log(PGAPVOL) } & & 0.0229 & & $-0.105^{\star \star \star}$ \\
\hline & & $(0.0245)$ & & $(0.0248)$ \\
\hline \multirow[t]{2}{*}{ Log(GDPC) } & $-0.325^{\star \star \star}$ & $-0.338 * \star \star$ & 0.0126 & 0.0426 \\
\hline & $(0.0558)$ & $(0.0572)$ & $(0.0728)$ & $(0.0665)$ \\
\hline \multirow[t]{2}{*}{ Log(GRVOL) } & $0.215^{\star \star \star}$ & $0.221^{\star \star \star}$ & $0.256 * \star \star$ & $0.255^{\star \star \star}$ \\
\hline & $(0.0179)$ & $(0.0167)$ & $(0.0344)$ & (0.0409) \\
\hline \multirow[t]{2}{*}{ Log(INFLVOL) } & $0.136^{\star \star \star}$ & $0.136^{\star \star \star}$ & $0.136 * \star \star \star$ & $0.124^{\star \star \star}$ \\
\hline & $(0.0207)$ & (0.0198) & $(0.0164)$ & $(0.0154)$ \\
\hline \multirow[t]{2}{*}{ Log(OPENSW) } & $-0.108 * \star$ & $-0.0977 \star \star$ & -0.0375 & -0.0403 \\
\hline & $(0.0417)$ & $(0.0428)$ & $(0.0341)$ & $(0.0340)$ \\
\hline \multirow[t]{2}{*}{ POLITY2 } & -0.00112 & -0.00121 & $-0.0179 * \star$ & $-0.0198 * \star \star$ \\
\hline & $(0.00495)$ & $(0.00446)$ & $(0.00716)$ & (0.00659) \\
\hline \multirow[t]{2}{*}{ Constant } & $-1.283^{\star *}$ & $-1.135^{\star \star}$ & $-3.212^{\star \star \star}$ & $-3.366 * \star \star$ \\
\hline & $(0.494)$ & $(0.451)$ & $(0.775)$ & $(0.722)$ \\
\hline $\begin{array}{l}\text { Observations - } \\
\text { Countries }\end{array}$ & $602-112$ & $597-112$ & $500-112$ & $495-112$ \\
\hline Within R-squared & 0.2603 & 0.2658 & & \\
\hline $\begin{array}{l}\text { Number of } \\
\text { Instruments }\end{array}$ & & & 72 & 72 \\
\hline AR1 (P-Value) & & & 0.0000 & 0.0000 \\
\hline AR2 (P-Value) & & & 0.7025 & 0.6327 \\
\hline
\end{tabular}




\begin{tabular}{|lll|} 
AR3 (P-Value) & 0.3498 & 0.2909 \\
\hline OID (P-Value) & 0.3451 & 0.5724 \\
\hline
\end{tabular}

Note: ${ }^{*} p$-value $<0,1 ; *{ }^{*} p$-value $<0,05 ; * \star * p$-value $<0,01$. Robust Standard errors are in parenthesis. All variables used in the regressions have been standardized. The variables "PHC", "PGAP", "OPENSW", "GRVOL", and "POLITY2" have been considered as endogenous. The latter have used 3 lags of the dependent variable as instruments, and 2 lags of endogenous variables as instruments.

Table 2: Effect of Poverty volatility on Non-resource tax revenue instability for varying levels of real per capita income

Estimator. Two-Step System GMM 


\begin{tabular}{|c|c|c|}
\hline \multirow[t]{2}{*}{ Variables } & Log(NRTAXINST) & Log(NRTAXINST) \\
\hline & (1) & (2) \\
\hline \multirow[t]{2}{*}{$\log (N R T A X I N S T)_{t-1}$} & $0.177^{\star \star \star}$ & $0.198 * \star *$ \\
\hline & $(0.0241)$ & $(0.0264)$ \\
\hline \multirow[t]{2}{*}{ Log(PHCVOL) } & $0.433^{\star \star *}$ & \\
\hline & $(0.145)$ & \\
\hline \multirow[t]{2}{*}[\operatorname{Log}(\mathrm{PHCVOL})]{$^{\star}[\log (\mathrm{GDPC})]$} & 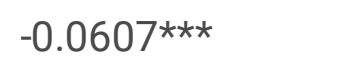 & \\
\hline & $(0.0166)$ & \\
\hline \multirow[t]{2}{*}{ Log(PGAPVOL) } & & $0.281^{\star \star}$ \\
\hline & & $(0.122)$ \\
\hline \multirow[t]{2}{*}[\operatorname{Log}(\text{PGAPVOL})]{$*[\log (G D P C)]$} & & $-0.0440 * \star \star$ \\
\hline & & $(0.0134)$ \\
\hline \multirow[t]{2}{*}{$\log (G D P C)$} & $-0.213^{\star \star \star}$ & $-0.121 * \star$ \\
\hline & $(0.0593)$ & $(0.0551)$ \\
\hline \multirow[t]{2}{*}{ Log(GRVOL) } & $0.272 * \star \star$ & $0.268 * \star \star$ \\
\hline & $(0.0252)$ & $(0.0275)$ \\
\hline \multirow[t]{2}{*}{ Log(INFLVOL) } & $0.133^{\star \star \star \star}$ & 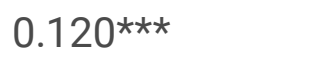 \\
\hline & $(0.0126)$ & $(0.0115)$ \\
\hline \multirow[t]{2}{*}{ Log(OPENSW) } & $-0.0450 *$ & -0.0341 \\
\hline & $(0.0257)$ & $(0.0253)$ \\
\hline \multirow[t]{2}{*}{ POLITY2 } & $-0.0184^{\star \star \star}$ & $-0.0184 * \star \star$ \\
\hline & (0.00565) & $(0.00432)$ \\
\hline \multirow[t]{2}{*}{ Constant } & $-1.268 * \star$ & $-1.891 * \star \star$ \\
\hline & $(0.546)$ & $(0.570)$ \\
\hline Observations - Countries & $500-112$ & $495-112$ \\
\hline Number of Instruments & 84 & 84 \\
\hline AR1 (P-Value) & 0.0000 & 0.0000 \\
\hline AR2 (P-Value) & 0.6921 & 0.5781 \\
\hline AR3 (P-Value) & 0.3289 & 0.2750 \\
\hline
\end{tabular}




\begin{tabular}{|c|c|c|}
\hline OID (P-Value) & 0.5273 & 0.6164 \\
\hline
\end{tabular}

Note: ${ }^{*} p$-value $<0,1 ; * * p$-value $<0,05 ; * * x$-value $<0,01$. Robust Standard errors are in parenthesis. All variables used in the regressions have been standardized. The variables "PHCVOL", "PGAPVOL", "OPENSW", "GRVOL", "POLITY2" and the interaction variables have been considered as endogenous. The latter have used 3 lags of the dependent variable as instruments, and 2 lags of endogenous variables as instruments.

Table 3: Effect of Poverty volatility on Non-resource tax revenue instability for varying levels of poverty Estimator. Two-Step System GMM 


\begin{tabular}{|c|c|c|c|c|}
\hline Variables & Log(NRTAXINST) & Log(NRTAXINST) & Log(NRTAXINST) & Log(NRTAXINST) \\
\hline & (1) & (2) & (3) & (4) \\
\hline \multirow{2}{*}{$\begin{array}{l}\log (\text { NRTAXINST) })_{\mathrm{t}} \\
1\end{array}$} & $0.197 * \star \star$ & $0.217 * \star \star$ & $0.183^{\star * \star}$ & $0.189 * \star \star$ \\
\hline & $(0.0188)$ & $(0.0167)$ & $(0.0135)$ & $(0.0163)$ \\
\hline \multirow{2}{*}{$\begin{array}{l}{[\mathrm{LOg}(\mathrm{PHCVOL})]^{\star}} \\
{[\mathrm{PHC}]}\end{array}$} & $0.00213^{\star \star *}$ & & & \\
\hline & $(0.000400)$ & & & \\
\hline \multirow{2}{*}{$\begin{array}{l}{[\mathrm{Log}(\mathrm{PGAPVOL})]^{\star}} \\
{[\mathrm{PGAP}]}\end{array}$} & & 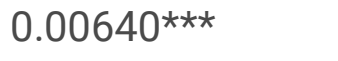 & & \\
\hline & & $(0.000881)$ & & \\
\hline \multirow{2}{*}{$\begin{array}{l}{[\mathrm{Log}(\mathrm{PHCVOL})]^{\star}} \\
{[\mathrm{GRPHC}]}\end{array}$} & & & $0.0427^{\star \star \star}$ & \\
\hline & & & $(0.0126)$ & \\
\hline \multirow{2}{*}{$\begin{array}{l}{[\text { Log(PGAPVOL)]* }} \\
\text { [GRPGAP] }\end{array}$} & & & & $0.0392 * \star \star$ \\
\hline & & & & $(0.0141)$ \\
\hline \multirow[t]{2}{*}{ Log(PHCVOL) } & $-0.0990 * * \star$ & & $-0.135^{\star \star \star}$ & \\
\hline & $(0.0140)$ & & $(0.0168)$ & \\
\hline \multirow[t]{2}{*}{ Log(PGAPVOL) } & & $-0.122^{\star \star \star}$ & & $-0.0774^{\star \star \star}$ \\
\hline & & (0.00933) & & (0.0198) \\
\hline \multirow[t]{2}{*}{$\mathrm{PHC}$} & $0.0107 \star \star \star$ & & & \\
\hline & $(0.00227)$ & & & \\
\hline \multirow[t]{2}{*}{ PGAP } & & 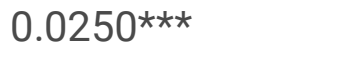 & & \\
\hline & & $(0.00414)$ & & \\
\hline \multirow[t]{2}{*}{ GRPHC } & & & -0.00792 & \\
\hline & & & $(0.0364)$ & \\
\hline \multirow[t]{2}{*}{ GRPGAP } & & & & $-0.120 * \star$ \\
\hline & & & & $(0.0604)$ \\
\hline \multirow[t]{2}{*}{ Log(GDPC) } & 0.0472 & $0.0602^{\star}$ & 0.0137 & $-0.0613^{\star \star \star}$ \\
\hline & $(0.0507)$ & $(0.0363)$ & $(0.0324)$ & $(0.0200)$ \\
\hline
\end{tabular}




\begin{tabular}{|c|c|c|c|c|}
\hline \multirow[t]{2}{*}{ Log(GRVOL) } & $0.226 * \star \star$ & $0.231^{\star \star \star}$ & $0.216^{\star \star \star}$ & $0.211^{\star \star \star}$ \\
\hline & $(0.0154)$ & $(0.0131)$ & $(0.0250)$ & $(0.0233)$ \\
\hline \multirow[t]{2}{*}{ Log(INFLVOL) } & $0.150 * \star \star$ & $0.138 * \star \star$ & $0.142^{\star \star \star}$ & 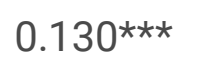 \\
\hline & $(0.00963)$ & $(0.00863)$ & $(0.0111)$ & (0.00905) \\
\hline \multirow[t]{2}{*}{ Log(OPENSW) } & -0.0260 & 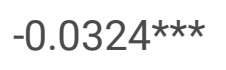 & $-0.0389 * *$ & $-0.0288^{\star \star}$ \\
\hline & $(0.0188)$ & $(0.0112)$ & $(0.0191)$ & $(0.0120)$ \\
\hline \multirow[t]{2}{*}{ POLITY2 } & $-0.0143^{\star \star *}$ & $-0.0172^{\star \star \star}$ & $-0.0126 * *$ & $-0.0203^{\star \star *}$ \\
\hline & $(0.00308)$ & $(0.00278)$ & $(0.00491)$ & (0.00314) \\
\hline \multirow[t]{2}{*}{ Constant } & $-3.366^{\star \star \star}$ & $-3.434^{\star \star \star}$ & $-3.291 * \star \star$ & $-2.408 * \star \star$ \\
\hline & $(0.469)$ & $(0.289)$ & $(0.336)$ & $(0.245)$ \\
\hline $\begin{array}{l}\text { Observations - } \\
\text { Countries }\end{array}$ & $500-112$ & $495-112$ & $500-112$ & $495-112$ \\
\hline $\begin{array}{l}\text { Number of } \\
\text { Instruments }\end{array}$ & 96 & 96 & 96 & 96 \\
\hline AR1 (P-Value) & 0.0000 & 0.0000 & 0.0000 & 0.0000 \\
\hline AR2 (P-Value) & 0.7614 & 0.6682 & 0.7026 & 0.7287 \\
\hline AR3 (P-Value) & 0.2996 & 0.2325 & 0.3012 & 0.3075 \\
\hline OID (P-Value) & 0.6759 & 0.6770 & 0.3642 & 0.7374 \\
\hline
\end{tabular}

Note: ${ }^{*} p$-value $<0,1 ; * *$-value $<0,05 ; * * * p$-value $<0,01$. Robust Standard errors are in parenthesis. All variables used in the regressions have been standardized. The variables "PHCVOL", "PGAPVOL", "PHC", "PGAP", "GRPHC", "GRPGAP", "OPENSW", "GRVOL", "POLITY2" and the interaction variables have been considered as endogenous. The latter have used 3 lags of the dependent variable as instruments, and 2 lags of endogenous variables as instruments.

\section{Figures}




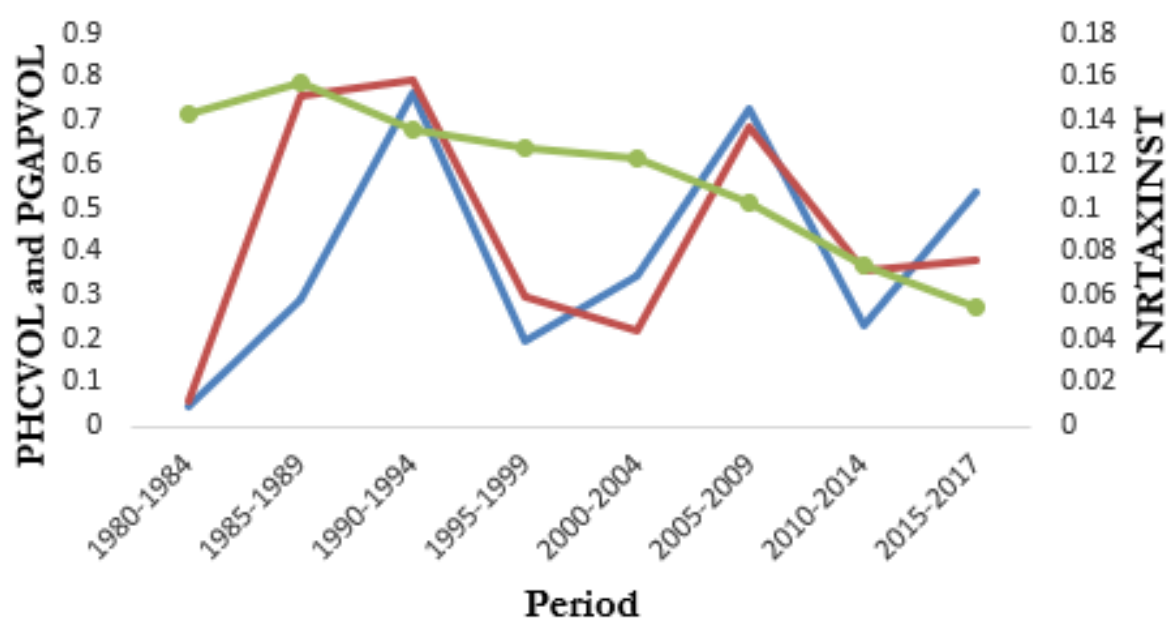

Figure 1

Poverty volatility and Non-resource tax revenue instability_Over the full sample Source: Author

\section{Supplementary Files}

This is a list of supplementary files associated with this preprint. Click to download.

- Appendix.docx 